\title{
PENGARUH LAND APPLICATION TERHADAP KUALITAS AIR TANAH DAN AIR PERMUKAAN DI KAWASAN PT.MISP BENGKAYANG
}

\author{
Lufika Virgianti ${ }^{1}{ }$ Marsudi $^{2}$, Winardi Yusuf ${ }^{1}$ \\ ${ }^{1}$ Program Studi Teknik Lingkungan Jurusan Teknik Sipil Fakultas Teknik Universitas Tanjungpura, Pontianak \\ ${ }^{2}$ Program Studi Teknik Sipil Jurusan Teknik Sipil Fakultas Teknik Universitas Tanjungpura, Pontianak \\ Email: sadlullabies@gmail.com
}

\begin{abstract}
ABSTRAK
PT.MISP Bengkayang mengaplikasikan land application dengan menggunakan limbah cair hasil produksi kelapa sawit yang mengandung bahan organik sebagai pupuk cair di lahan perkebunannya sehingga mempunyai potensi mencemari air tanah dan air permukaan. Tujuan dari penelitian ini adalah untuk mengetahui seberapa besar pengaruh land application terhadap kualitas air tanah dan air permukaan di kawasan perkebunan dan untuk mengetahui penyebaran kontaminan yang ada pada lahan aplikasi dan lahan non aplikasi PT.MISP Bengkayang.

Metode penelitian dilakukan dengan pengukuran elevasi dan muka air tanah, pengukuran debit air permukaan dan pengambilan sampel air dengan metode grab sampling yang dilakukan di musim kering pada 1 titik di kolam terakhir IPAL, 2 titik pada sungai yang diambil di hulu dan hilir dan masing-masing 5 titik pada lahan aplikasi dan lahan non aplikasi kemudian dilakukan pengujian kualitas air terhadap parameter BOD, TSS, $\mathrm{NH}_{3}, \mathrm{pH}$ dan $\mathrm{DO}$.

Hasil yang didapat yaitu konsentrasi BOD, TSS, $\mathrm{NH}_{3}$ dan DO pada lahan aplikasi lebih besar dari nilai yang ada di lahan non aplikasi sebagai lahan kontrol, serta pada hulu dan hilir sungai. Namun konsentrasi TSS dan $\mathrm{NH}_{3}$ pada air permukaan dipengaruhi oleh faktor luar, sedangkan nilai $\mathrm{pH}$ masih berada dalam rentang normal. Dapat disimpulkan bahwa land application pada musim kering mempunyai pengaruh terhadap kualitas air tanah dan air permukaan pada kawasan tersebut. Penyebaran BOD pada lahan aplikasi dipengaruhi oleh kondisi lahan dan bentuk aliran air tanah, dan pada lahan non aplikasi dipengaruhi oleh vegetasi penutup lahan. Nilai TSS, $\mathrm{NH}_{3}$ dan $\mathrm{DO}$ berhubungan dengan BOD.
\end{abstract}

Kata kunci : land application, kualitas air, air tanah, penyebaran kontaminan.

\section{ABSTRACT}

PT.MISP Bengkayang apply land application using wastewater of palm oil production containing organic material as a liquid fertilizer on plantation areas that have the potential to contaminate groundwater and surface water. The purpose of this research is to determine how much influence of land application on groundwater quality and surface water in the plantation areas and to determine the movement of contaminants on application land and non-application land at PT.MISP Bengkayang.

The research method is done by measuring the ground elevation and ground water, surface water discharge measurements and water sampling with grab sampling method in the dry season at 1 point in the final pool WWTP, 2 points on the river taken in the upstream and downstream and each 5 points on application land of non-application land then testing the water quality of BOD, $\mathrm{TSS} \mathrm{NH}_{3}, \mathrm{pH}$ and $D O$.

The result showed that concentration of $\mathrm{BOD}, \mathrm{TSS}, \mathrm{NH}_{3}$ and $\mathrm{DO}$ on application land is greater than the existing value in the non-application land as control, as well as upstream and downstream. However, TSS and $\mathrm{NH}_{3}$ concentration in surface water is affected by external factors, while the $\mathrm{pH}$ value remained within the normal range. It can be concluded that land application in the dry season has an influence on the quality of ground water and surface water in that area. Movement of BOD in application land affected by soil conditions and forms of groundwater flow, and in non-application land affected by land vegetation. Value of TSS, $\mathrm{NH}_{3}$ and DO relate to the $\mathrm{BOD}$.

Keywords : land application, water quality, ground water, the movement of contaminants.

\section{PENDAHULUAN}

Kelapa sawit adalah tumbuhan yang merupakan salah satu komoditi andalan Indonesia yang perkembangannya demikian pesat. PT. MISP Bengkayang mengaplikasikan land application dengan menggunakan limbah hasil produksi kelapa sawit yang masih mengandung 
bahan organik sebagai pupuk cair di lahan perkebunannya. Dari sisi lingkungan bahan organik yang tinggi ini dapat mencemari air tanah dan air permukaan, maka dari itu perlu dilakukan penelitian tentang seberapa besar pengaruh land application ini terhadap kualitas air tanah dan air permukaan yang dilakukan pada salah satu lahan perkebunan PT. Mitra Inti Sejati Plantation (PT. MISP).

\section{METODOLOGI PENELITIAN}

Lokasi penelitian berada di kawasan perkebunan dan pabrik kelapa sawit (PKS) PT. Mitra Inti Sejati Plantation (PT.MISP) Kabupaten Bengkayang, Provinsi Kalimantan Barat. Pengambilan sampel air limbah, air tanah dan air permukaan dilakukan pada tanggal 27 Februari - 1 Maret 2014.

\section{A. Pengumpulan Data}

Data sekunder yang digunakan antara lain berupa peta (peta administrasi, peta lokasi perkebunan, dan peta lokasi PKS dan land application) dan jadwal aplikasi land application (jadwal pengaliran). Pengumpulan data primer dilakukan dengan survei lokasi penelitian, pengukuran elevasi tanah, muka air tanah pada lahan aplikasi dan non aplikasi, pengukuran debit air permukaan, pengambilan sampel air dengan metode grab sample, pengujian kualitas air limbah, air tanah dan air permukaan.

\section{B. Pengambilan Sampel}

Pengambilan sampel akan dilakukan pada 13 titik, 1 titik di kolam terakhir IPAL, 5 titik di lahan aplikasi dan 5 titik di lahan non aplikasi, dan 2 titik pada sungai yang diambil di hulu dan hilir sebelum dan sesudah lahan aplikasi. Dengan luas tiap lahan \pm 30 ha $(300 \mathrm{~m} \times 1000 \mathrm{~m})$, titik pengambilan sampel di lahan aplikasi dilakukan di samping salah satu jalur flatbed di tengah lahan, ditentukan lima titik pengambilan sampel dengan jarak tiap titik sebesar 60 meter, sedangkan pengambilan sampel air tanah pada lahan non aplikasi dilakukan pada gawangan di tengah lahan dengan titik pengambilan sampel ditentukan sebanyak lima titik, sama dengan lahan aplikasi dimana antar titik berjarak 60 meter.

\section{Analisis Data}

Analisis data dilakukan dengan pengujian sampel air. Hasil berupa data kualitas air yang telah diperoleh dari analisis di laboratorium disajikan dalam bentuk tabel dan gambar (grafik), membandingkan dengan baku mutu lingkungan pada Peraturan Pemerintah Republik Indonesia Nomor 82 Tahun 2001 untuk klasifikasi mutu air kelas II dan membandingkan antara kualitas air tanah pada lahan aplikasi dan non aplikasi, serta kualitas air permukaan di hulu dan di hilir. Tahapan analisis penyebaran kontaminan pada lahan aplikasi dan lahan non aplikasi dilakukan untuk tujuan mempelajari tingkah laku dari kontaminan yang terbawa aliran air tanah, dengan menentukan gambaran penyebaran kontaminan yang ditunjukkan melalui grafik antara konsentrasi vs jarak pusat pencemaran dari titik pengambilan sampel. 


\section{HASIL DAN PEMBAHASAN}

\section{A. Data Hasil Penelitian Kualitas Air}

\section{a. Elevasi dan Muka Air}

Hasil pengukuran elevasi dan muka air tanah pada lahan aplikasi dan lahan non aplikasi dapat dilihat pada gambar 1 (Hasil Analisis, 2014).

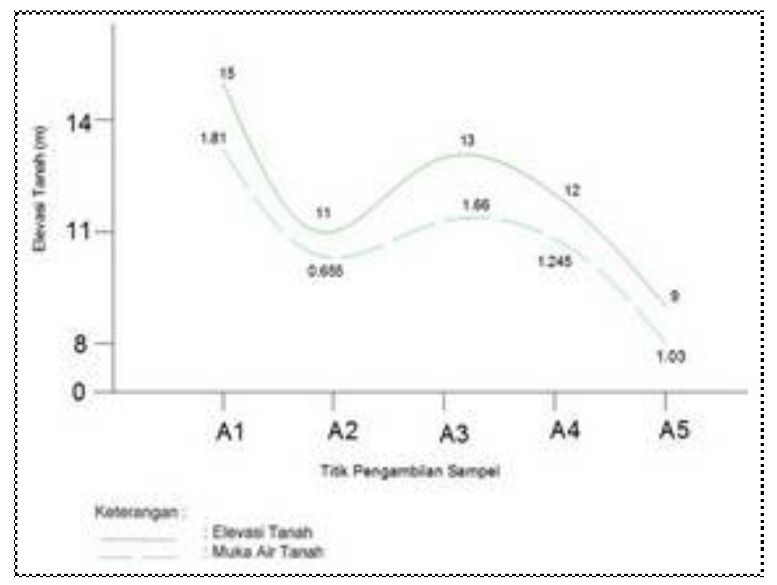

(a) Lahan Aplikasi

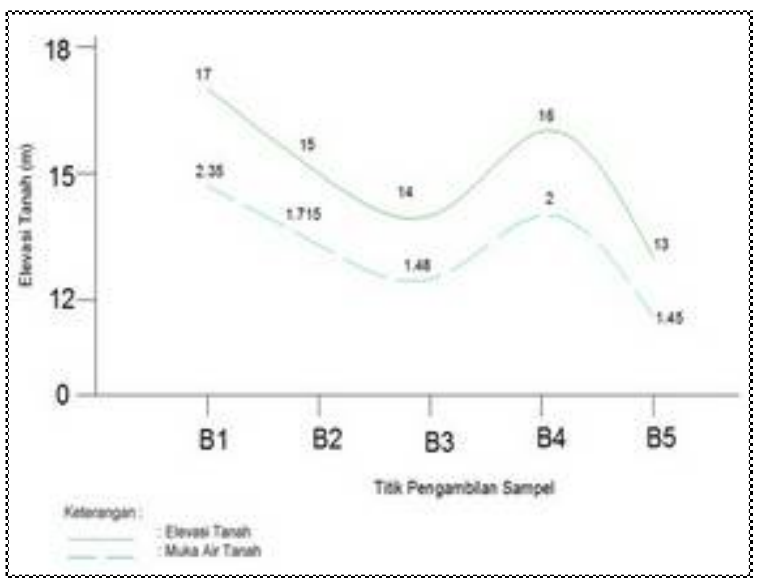

(b)Lahan Non Aplikasi

Gambar 1. Elevasi tanah dan muka air tanah pada tiap lahan

Gambar 1 menunjukkan bahwa aliran air tanah di lahan aplikasi dan lahan non aplikasi cenderung mengikuti elevasi tanah, dimana menurut Verstappen dan Zuidam (1975), bentuk lahan akan mempunyai respon tertentu terhadap air tanah, karena kedudukan muka air tanah mengikuti pola topografi permukaan, serta air tanah akan mengalir di bawah pengaruh gravitasi. Air tanah pada lahan aplikasi dan lahan non aplikasi mengalir dari titik 1 ke titik 5 karena adanya beda ketinggian, titik A1 dengan elevasi 15 meter dan titik A5 dengan elevasi 9 meter, titik B1 17 meter dan titik B5 13 meter.

\section{b. Elevasi Air Permukaan}

Hasil pengukuran elevasi pada air permukaan dapat dilihat pada gambar 2 (Hasil Analisis, 2014).

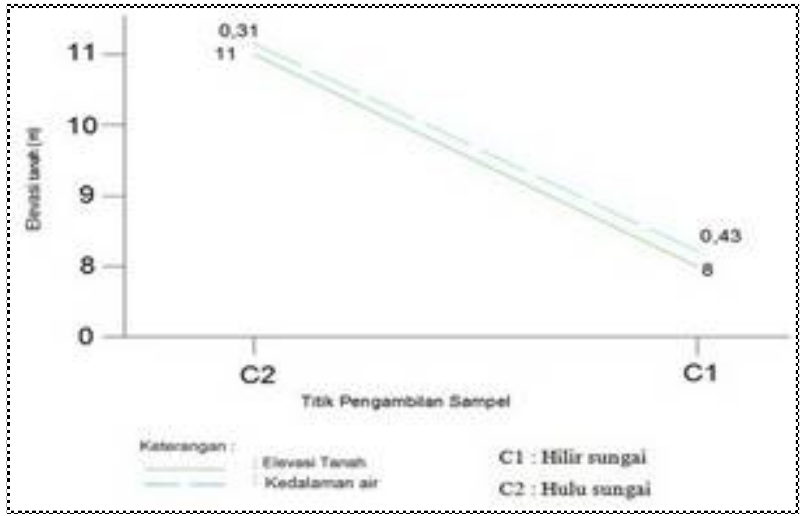

Gambar 2. Elevasi dan kedalaman pada air permukaan

Dapat dilihat pada gambar tersebut, elevasi tanah pada titik C2 lebih tinggi daripada titik C1 sehingga air mengalir dari C2 ke C1. Muka air pada titik C2 lebih rendah daripada C1 yang disebabkan selain musim kering, adanya penyedotan air pada daerah tersebut yang digunakan untuk mengairi lahan sawit, mengakibatkan air pada hulu sungai menjadi lebih sedikit 
dibandingkan dengan air yang terdapat di hilir. Muka air yang sangat rendah ini diakibatkan oleh musim kering yang cukup ekstrim, dimana hujan tidak turun selama berminggu-minggu, sehingga perusahaan pun menggunakan air sungai sebagai sumber pengairan untuk lahan sawit.

\section{B. Analisis Land Application terhadap Kualitas Air}

\section{a. Kualitas Air Limbah}

Data kualitas air limbah dapat dilihat pada tabel berikut ini (PT. SUCOFINDO, 2014) :

Tabel 1. Kualitas Air Limbah

\begin{tabular}{|c|c|c|c|c|c|}
\hline No & Parameter & Nilai & $\begin{array}{c}\text { Baku Mutu PP RI Nomor 82 } \\
\text { Tahun 2001 }\end{array}$ & $\begin{array}{c}\text { Baku Mutu Kepmen LH Nomor } \\
\text { 28 Tahun 2003 }\end{array}$ & Satuan \\
\hline 1 & BOD & 2048 & 2 & $5000 \mathrm{mg} / \mathrm{l}$ & $\mathrm{mg} / \mathrm{l}$ \\
\hline 2 & $\mathrm{TSS}$ & 6176 & 50 & - & $\mathrm{mg} / \mathrm{l}$ \\
\hline 3 & $\mathrm{pH}$ & 7,06 & $6-9$ & $6-9$ & \\
\hline 4 & $\mathrm{NH}_{3}$ & 175,75 & 0,02 & - & $\mathrm{mg} / \mathrm{l}$ \\
\hline 5 & $\mathrm{DO}$ & 0,1 & 6 & - & $\mathrm{mg} / \mathrm{l}$ \\
\hline
\end{tabular}

Dapat dilihat dari tabel tersebut bahwa kualitas awal limbah mempunyai nilai BOD, TSS dan $\mathrm{NH}_{3}$ yang sangat tinggi serta nilai DO yang sangat rendah. Hampir semua parameter melebihi ambang batas untuk untuk berada pada lingkungan seperti yang ditentukan dalam PP RI Nomor 82 Tahun 2001 kecuali untuk nilai pH, ini berarti bahwa limbah dari kolam terakhir IPAL tidak bisa dibuang langsung karena akan berbahaya bagi lingkungan. Namun nilai BOD dan $\mathrm{pH}$ tersebut sudah masuk kategori aman untuk diaplikasikan ke lahan seperti yang ditentukan dalam Kepmen LH Nomor 28 Tahun 2003. Nilai BOD yang masih tinggi ini merupakan hasil dari pengolahan pada kolam anaerobik primer di mana perombakan oleh mikroorganisme belum terjadi secara sempurna yang tentunya hal ini bertujuan untuk mempertahankan bahan-bahan organik dalam limbah untuk diaplikasikan pada lahan, dan hal ini berpengaruh terhadap nilai DO yang sangat rendah. Nilai $\mathrm{NH}_{3}$ yang sangat tinggi ini mengindikasikan banyaknya nitrogen dalam air limbah yang dirombak oleh mikroorganisme seperti yang dijelaskan oleh Floyd et al (2009). Kandungan nitrogen yang tinggi ini dipertahankan sebagai unsur hara yang penting bagi kesuburan tumbuhan sawit. Sedangkan untuk nilai $\mathrm{pH}$, menunjukkan nilai 7,06 dimana nilai ini termasuk dalam rentang $\mathrm{pH}$ normal. Nopianto (2010) menjelaskan bahwa pada kolam anaerobik terjadi penetralan pH dengan resirkulasi limbah keluaran dari kolam anaerobik ke parit masukan kolam anaerobik agar perombakan asam organik oleh bakteri anaerob terjadi secara optimal. Nilai pH yang normal pada hasil uji air limbah pada kolam anaerobik ini menunjukkan bahwa pengolahan limbah pada kolam anaerobik (kolam terakhir IPAL) sudah terjadi dengan baik sehingga nilai pH ini tidak berpengaruh secara langsung terhadap lingkungan.

\section{b. Analisis Pengaruh Land Application terhadap Kualitas Air Tanah}

Data kualitas air tanah ini adalah kualitas air tanah pada lahan aplikasi dan lahan non aplikasi, yang mana kualitas air pada lahan non aplikasi digunakan sebagai kontrol untuk menunjukkan kualitas awal air tanah pada kawasan tersebut. Data kualitas air tanah dapat dilihat pada tabel berikut ini (PT.SUCOFINDO, 2014) : 
Tabel 2. Kualitas Air Tanah pada Lahan Aplikasi

\begin{tabular}{|c|c|c|c|c|c|c|}
\hline No & Kode & $\mathrm{BOD}(\mathrm{mg} / \mathrm{l})$ & $\mathrm{TSS}(\mathrm{mg} / \mathrm{l})$ & $\mathrm{pH}$ & $\mathrm{NH}_{3}(\mathrm{mg} / \mathrm{l})$ & $\mathrm{DO}(\mathrm{mg} / \mathrm{l})$ \\
\hline 1 & $\mathrm{~A} 1$ & 30 & 342 & 6,9 & 5,78 & 2,1 \\
\hline 2 & $\mathrm{~A} 2$ & 41 & 126 & 7,02 & 6,43 & 1,53 \\
\hline 3 & $\mathrm{~A} 3$ & 31,52 & 228 & 6,94 & 5,78 & 2,3 \\
\hline 4 & $\mathrm{~A} 4$ & 22,4 & 220 & 6,9 & 5,62 & 2,21 \\
\hline 5 & $\mathrm{~A} 5$ & 27,69 & 234 & 6,92 & 5,94 & 1,94 \\
\hline
\end{tabular}

Tabel 3. Kualitas Air Tanah pada Lahan Non Aplikasi

\begin{tabular}{|c|c|c|c|c|c|c|}
\hline No & Kode & BOD $(\mathrm{mg} / \mathrm{l})$ & $\mathrm{TSS}(\mathrm{mg} / \mathrm{l})$ & $\mathrm{pH}$ & $\mathrm{NH}_{3}(\mathrm{mg} / \mathrm{l})$ & $\mathrm{DO}(\mathrm{mg} / \mathrm{l})$ \\
\hline 1 & B1 & 18 & 120 & 6,92 & 5 & 2,38 \\
\hline 2 & B2 & 25,67 & 60 & 6,94 & 5,3 & 2,18 \\
\hline 3 & B3 & 23 & 78 & 6,96 & 4,98 & 2,32 \\
\hline 4 & B4 & 19,6 & 35 & 6,96 & 4,5 & 2,41 \\
\hline 5 & B5 & 18 & 40 & 7 & 4,4 & 2,45 \\
\hline
\end{tabular}

Sebagian besar parameter kualitas air pada lahan non aplikasi sebagai lahan kontrol sudah menunjukkan tercemarnya air tanah di kawasan tersebut, namun nilainya masih di bawah pencemaran yang terjadi di lahan aplikasi. Selain karena adanya faktor pemupukan yang berkontribusi dalam pemasukan bahan organik ke dalam air tanah, tidak adanya pengenceran oleh air hujan juga menjadi salah satu faktor yang memperparah pencemaran di lahan non aplikasi ini. Sedangkan pada lahan aplikasi, proses pengaliran limbah pada lahan telah mengakibatkan pencemaran dengan adanya perbedaan nilai parameter uji yang melebihi nilai yang ada di lahan non aplikasi, kecuali untuk nilai pH yang normal untuk kedua lahan. Maka dari itu land application mempunyai pengaruh terhadap kualitas air tanah saat musim kering di kawasan perkebunan ini.

\section{c. Analisis Pengaruh Land Application terhadap Kualitas Air Permukaan}

Kualitas air permukaan ini adalah kualitas air sungai yang berada di antara lahan perkebunan kelapa sawit dengan pabrik kelapa sawit (PKS) yang diambil dari hilir dan di hulu untuk mengetahui ada tidaknya pengaruh land application terhadap air permukaan. Kualitas air permukaan dapat dilihat pada tabel berikut ini (PT.SUCOFINDO, 2014) :

Tabel 4. Kualitas Air Permukaan

\begin{tabular}{|c|c|c|c|c|c|c|}
\hline No & Kode & BOD $(\mathrm{mg} / \mathrm{l})$ & $\begin{array}{c}\mathrm{TSS} \\
(\mathrm{mg} / \mathrm{l})\end{array}$ & $\mathrm{pH}$ & $\begin{array}{c}\mathrm{NH}_{3} \\
(\mathrm{mg} / \mathrm{l})\end{array}$ & $\mathrm{DO}(\mathrm{mg} / \mathrm{l})$ \\
\hline 1 & $\mathrm{C} 1$ & 84,5 & 24 & 6,5 & 0,64 & 1,27 \\
\hline 2 & $\mathrm{C} 2$ & 24 & 156 & 6,56 & 1,44 & 4,32 \\
\hline
\end{tabular}

Keterangan :

C1 : Hilir Sungai C2: Hulu Sungai

Tabel tersebut menunjukkan bahwa air permukaan pada kawasan tersebut juga telah mengalami pencemaran yang dapat dilihat dari nilai beberapa parameter yang telah melebihi ambang batas, seperti BOD, TSS, Amonia dan DO, yang terjadi karena adanya kontaminasi dari limbah yang berasal dari lahan aplikasi maupun dari IPAL, karena sungai merupakan bagian terendah dari daratan, maka air tanah maupun runoff yang mengalir dari lahan aplikasi dan PKS akan berakhir di sungai. Konsentrasi $\mathrm{NH}_{3}$ dan TSS yang besar pada hulu sungai dibanding hilir sungai terjadi karena faktor luar yaitu penyedotan air oleh perusahaan. Namun, dapat dilihat bahwa pencemaran yang terjadi pada air pemukaan tidak seburuk yang terjadi pada air tanah, hal ini terjadi karena kontaminan tidak secara langsung masuk ke dalam badan air, melainkan melaui air tanah dan melewati media tanah. 


\section{Analisis Penyebaran Kontaminan}

\section{a. Penyebaran BOD}

Penyebaran BOD di lahan aplikasi dan lahan non aplikasi dapat dilihat pada gambar berikut (Hasil Analisis, 2014) :

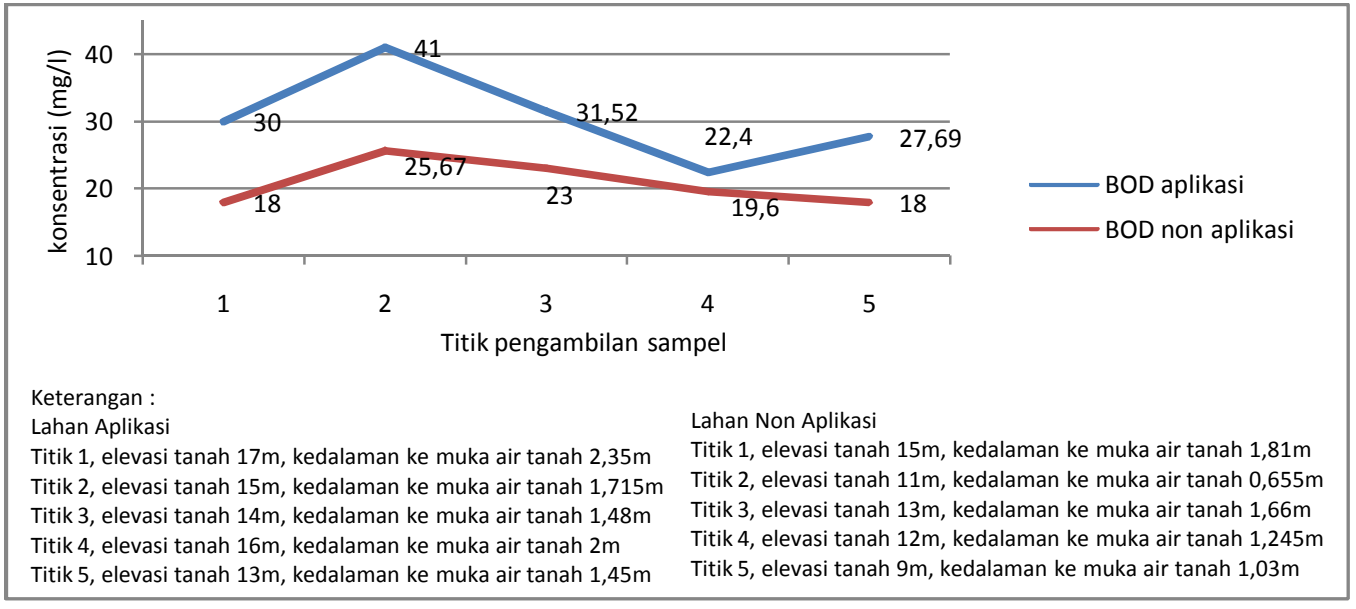

Gambar 3. Grafik penyebaran BOD

Konsentrasi BOD tertinggi pada lahan aplikasi terdapat pada titik kedua yang disebabkan dekatnya muka air tanah dengan permukaan tanah sehingga limbah yang mengalir di permukaan tanah lebih cepat kontak dengan air tanah karena tidak sempat tersaring oleh tanah sebagai filter. Peran tanah sebagai media penyaring dan muka air tanah yang berhubungan dengan lama kontak kontaminan dengan tanah sebelum bercampur dengan air tanah seperti yang dijelaskan oleh Piscopo (2001) tentang faktor yang mempengaruhi penyebaran kontaminan di air tanah. Selain itu, pengaruh kondisi lahan pada titik kedua yang merupakan cekungan, mengakibatkan tertahannya kontaminan pada titik tersebut sehingga aliran air tanah menuju titik ketiga yang memiliki muka air tanah lebih tinggi menjadi melambat dan juga memungkinkan adanya larian limbah dari flatbed lain ke arah cekungan sehingga konsentrasi BOD di titik kedua menjadi yang paling tinggi. Penurunan konsentrasi pada titik ketiga dan keempat disebabkan karena jarak antara permukaan tanah dan muka air tanah yang lebih jauh yaitu sebesar 1,66 meter pada titik ketiga dan 1,245 meter pada titik keempat, berbeda dengan titik kedua yang hanya memiliki jarak 0,655 meter sehingga menyebabkan limbah yang meresap dari permukaan tanah mengalami kontak lebih lama dengan tanah, selain itu adanya kenaikan muka air tanah di titik ketiga menyebabkan air tanah dan pencemar bergerak lebih lambat. Kenaikan konsentrasi BOD pada titik kelima disebabkan oleh akumulasi limbah dan kondisi lahan yang berelevasi rendah menyebabkan terjadinya cekungan seperti yang terjadi pada titik kedua.

Pada lahan non aplikasi, konsentrasi BOD di titik pertama lebih rendah dibanding titik kedua yang merupakan titik dengan konsentrasi BOD paling tinggi. Hal ini disebabkan karena kontaminan yang berupa pupuk terbawa oleh aliran air tanah ke titik kedua yang mengalami penurunan aliran air tanah. Kemudian konsentrasi BOD menurun di titik ketiga sampai titik kelima. Panjaitan (2008) menyebutkan bahwa fitoremediasi yaitu fungsi tanaman sebagai penutup lahan dengan menggunakan kemampuan tanaman untuk mendegradasi senyawa organik sehingga dapat mengurangi kontaminasi pada air tanah. Pada titik ketiga, keempat dan kelima, adanya vegetasi penutup lahan yg sangat rimbun pada daerah tersebut, berbeda dengan vegetasi yang ada pada titik 1 dan 2 yang memiliki vegetasi penutup lahan namun tidak serimbun titik 3, 4 dan 5 menyebabkan konsentrasi BOD menurun akibat adanya fitoremediasi. 


\section{b. Penyebaran TSS}

Setelah dilakukan pengujian di laboratorium didapatkan hasil penyebaran TSS pada lahan aplikasi dan lahan non aplikasi seperti yang ditunjukkan pada gambar 4 berikut (Hasil Analisis, 2014).

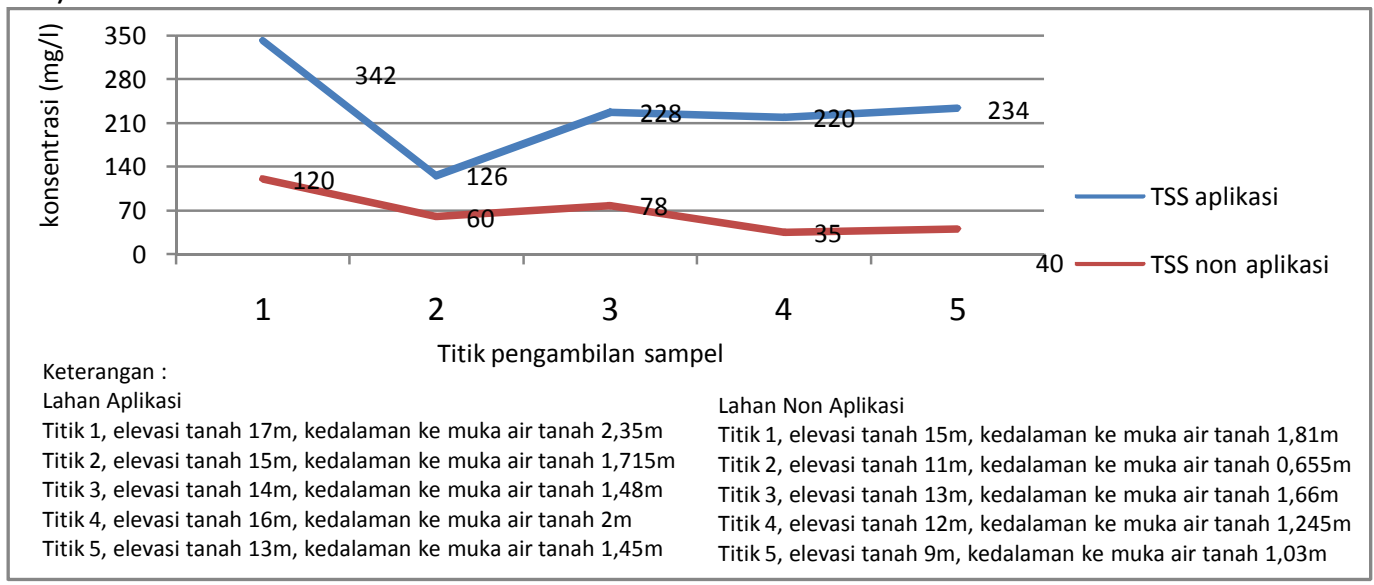

Gambar 4. Grafik penyebaran TSS

Nilai TSS yang tinggi pada titik 1 disebabkan karena bahan organik yang berasal dari limbah cair kelapa sawit pada kolam terakhir IPAL memiliki nilai TSS awal yang besar yaitu $6176 \mathrm{mg} / \mathrm{I}$ sehingga pengaliran limbah yang terus menerus pada titik tersebut mengakibatkan TSS yang tinggi. Adanya penurunan konsentrasi TSS pada titik kedua dapat disebabkan adanya aliran lain dari parit pada lahan yang terletak di dekat titik kedua kemudian masuk ke aliran air tanah karena kondisi cekungan pada lahan di titik kedua, sehingga air tanah pada titik kedua terencerkan. Kemudian konsentrasi kembali meningkat pada titik ketiga dan menurun pada titik keempat dan meningkat lagi pada titik kelima. Seperti yang telah disebutkan oleh Fardiaz (1992), konsentrasi TSS ini terjadi karena adanya akumulasi bahan organik yang terbawa aliran air tanah dari titik-titik sebelumnya.

Pada lahan non aplikasi, konsentrasi TSS tertinggi berada di titik pertama karena pemupukan pada lahan yang terjadi pada musim kering dan kurangnya vegetasi penutup lahan menyebabkan tingginya konsentrasi TSS pada titik pertama. Kemudian konsentrasi menurun pada titik kedua dan meningkat kembali pada titik ketiga. Fardiaz (1992) juga menjelaskan bahwa selain adanya bahan organik di dalam TSS, juga terdapat kandungan bahan lain seperti partikel tanah, tanah liat, bahan anorganik dan sebagainya, sehingga sulit untuk menentukan konsentrasi TSS yang diakibatkan oleh murni bahan organik. Kemungkinan bahwa konsentrasi TSS pada titik kedua dan ketiga disebabkan adanya bahanbahan lain dalam tanah, seperti partikel tanah itu sendiri yang bercampur dengan air tanah sehingga menyebabkan konsentrasi TSS yang tidak sesuai. Nilai TSS yang menurun pada titik keempat dan kelima dikarenakan adanya faktor fitoremediasi oleh vegetasi penutup lahan yang sangat rimbun yang ada di sekitar titik tersebut. 


\section{c. Penyebaran pH}

Nilai pH hasil uji laboratorium pada lahan aplikasi dan lahan non aplikasi dapat dilihat pada gambar 5 berikut (Hasil Analisis, 2014).

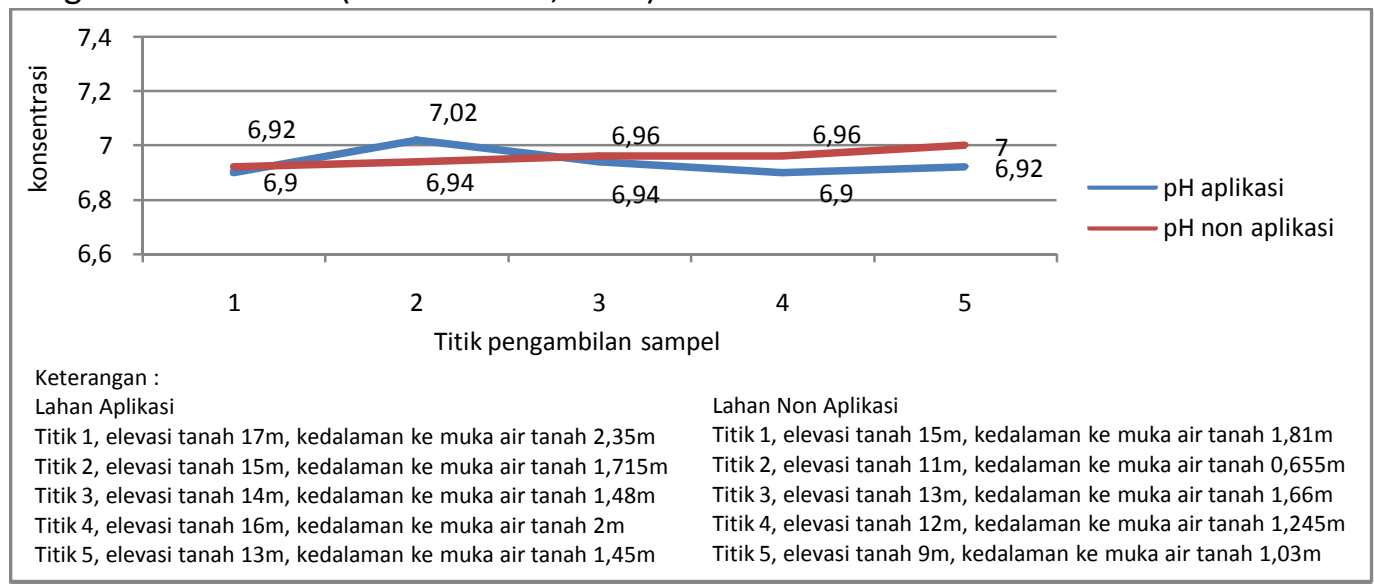

Gambar 5. Grafik penyebaran $\mathrm{pH}$

Grafik yang ditunjukkan oleh gambar 5 tersebut menunjukkan pergerakan nilai $\mathrm{pH}$ pada lahan aplikasi dan lahan non aplikasi yang stabil di mana nilai $\mathrm{pH}$ dari titik 1 sampai titik 5 berada pada rentang 6,9-7 dimana nilai $\mathrm{pH}$ tersebut termasuk dalam rentang $\mathrm{pH}$ normal. Rahayu dkk (2009) menyatakan bahwa pada kisaran pH 6,5-8,2 merupakan pH optimal bagi sebagian besar organisme khususnya organisme perairan, hal ini menunjukkan bahwa air tanah pada lahan aplikasi dan lahan non aplikasi mempunyai $\mathrm{pH}$ yang baik sehingga faktor $\mathrm{pH}$ dalam kontaminan tidak bepengaruh terhadap kualitas air tanah dan lingkungan.

\section{d. Penyebaran Amonia $\left(\mathrm{NH}_{3}\right)$}

Hasil uji laboratorium untuk kadar amonia pada lahan aplikasi dan lahan non aplikasi dapat dilihat pada gambar 6 berikut (Hasil Analisis, 2014).

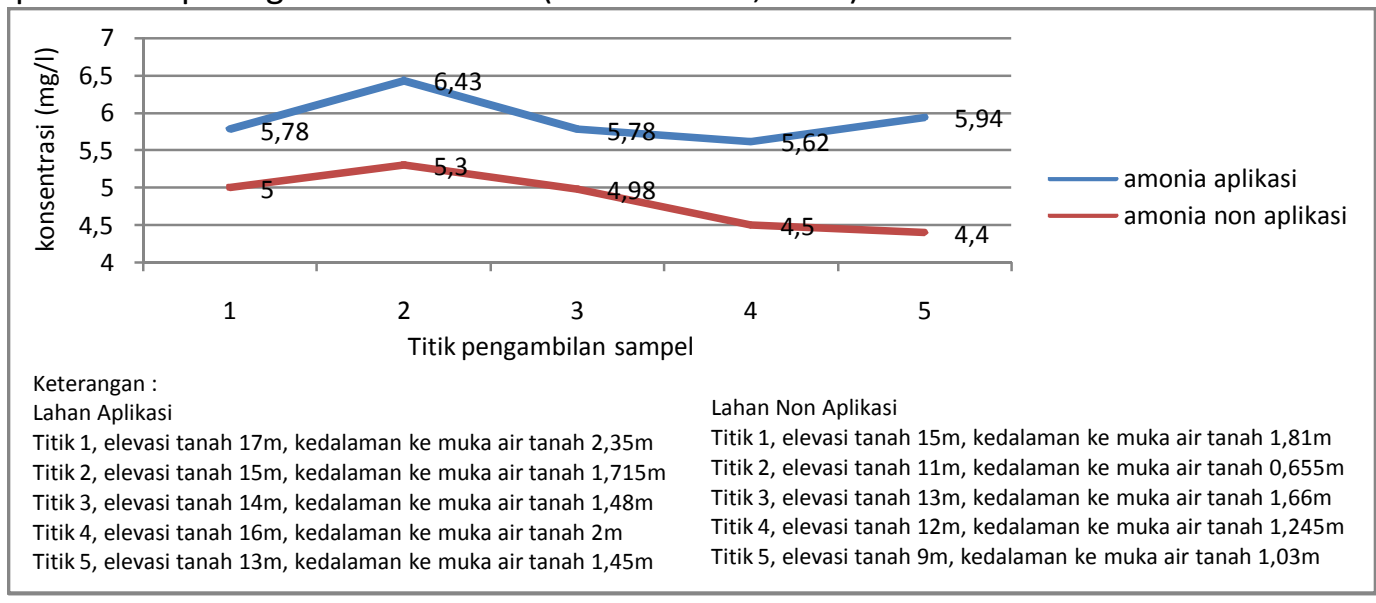

Gambar 6. Grafik penyebaran $\mathrm{NH}_{3}$

Dapat dilihat bahwa penyebaran amonia yang terjadi pada grafik di atas serupa dengan yang terjadi pada penyebaran BOD. Hal ini mengindikasikan bahwa BOD dan amonia pada lahan aplikasi dan lahan non aplikasi mempunyai hubungan yang sebanding. Menurut Rahayu dkk (2009), bahan organik berupa nitrogen yang ada dalam air tanah diuraikan oleh mikroorganisme menjadi amonia dengan menggunakan oksigen. Semakin banyak aktivitas penguraian, maka BOD pun meningkat begitu juga dengan nilai amonia, hal inilah yang 
menyebabkan penyebaran amonia pada lahan aplikasi maupun lahan non aplikasi mengikuti atau sebanding dengan penyebaran BOD.

\section{e. Penyebaran DO}

Hasil uji laboratorium menghasilkan grafik konsentrasi DO pada tiap titik pada lahan aplikasi dan lahan non aplikasi yang dapat dilihat pada gambar 7 berikut (Hasil Analisis, 2014).

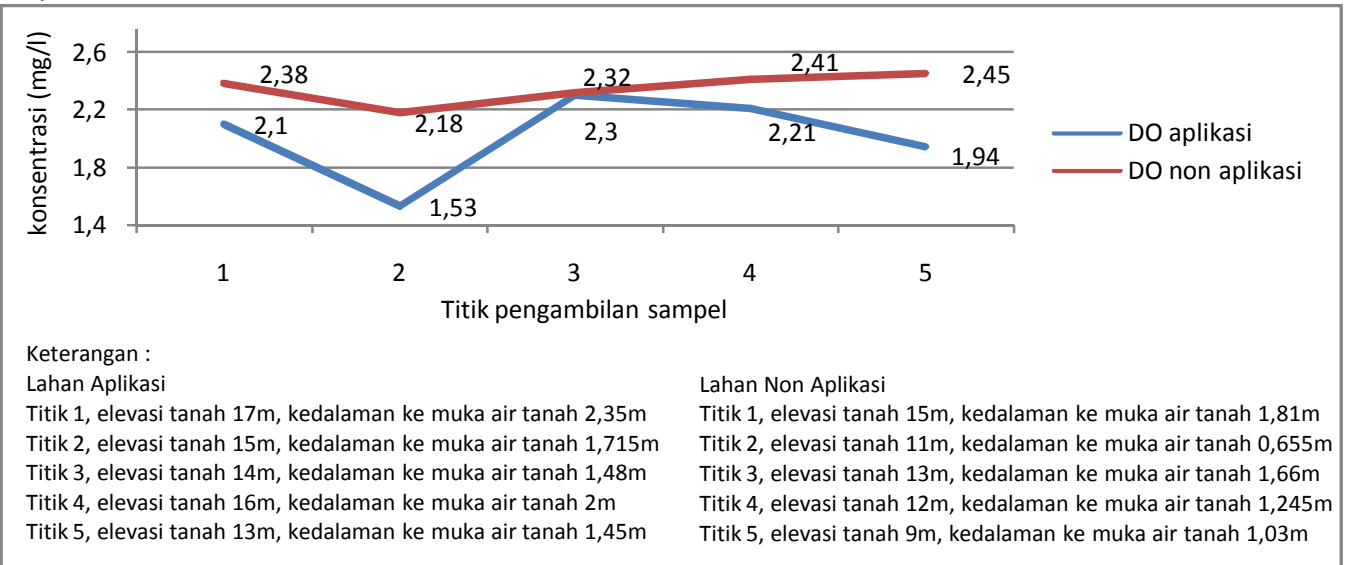

Gambar 7. Grafik penyebaran DO

Penyebaran DO pada lahan aplikasi mempunyai gambaran yang berbanding terbalik dengan BOD, dimana pada saat BOD tinggi, maka DO menjadi turun, hal ini disebabkan karena BOD dan DO saling berhubungan sebagaimana yang telah dijelaskan oleh Salmin (2005), BOD adalah besarnya oksigen yang diperlukan oleh mikroorganisme untuk menguraikan bahan organik yang ada dalam air, maka semakin banyak oksigen yang dibutuhkan, semakin sedikit pula kadar oksigen terlarut yang ada di dalam air. DO yang menurun pada titik kedua di lahan aplikasi disebabkan karena konsentrasi amonia yang tinggi, karena menurut Rahayu dkk (2009), proses perombakan amonia membutuhkan 4,5 bagian oksigen untuk setiap bagian amonia sehingga oksigen terlarut menjadi menurun drastis.

Sedangkan nilai DO pada lahan non aplikasi pada titik kedua terjadi penurunan konsentrasi DO karena dipengaruhi oleh BOD yang besar pada titik kedua, dan pada titik ketiga yang memiliki muka air tanah yang lebih rendah dari titik kedua memiliki konsentrasi DO yang lebih tinggi dari titik kedua. Hal ini dapat terjadi karena adanya vegetasi penutup lahan yang lebih rimbun dari titik pertama dan kedua. Menurut Effendi (2003), pergerakan akar dalam tanah dapat menyebabkan terbentuknya lubang dalam tanah yang akan terisi udara, dan akan berdifusi ke dalam air tanah, sehingga vegetasi penutup lahan ini memberikan pengaruh terhadap konsentrasi DO di dalam air tanah. Hal yang sama juga terjadi pada titik keempat dan kelima yang menunjukkan adanya peningkatan konsentrasi DO, karena selain adanya vegetasi penutup lahan yang berkontribusi dalam penyediaan oksigen di air tanah, bahan organik berlebih yang ada dalam air tanah juga didegradasi.

\section{KESIMPULAN}

Dari hasil penelitian yang telah dilakukan dapat ditarik kesimpulan sebagai berikut :

a. Land application mempunyai pengaruh terhadap kualitas air tanah dan air permukaan pada kawasan PT.MISP Bengkayang dilihat dari hasil pengujian laboratorium dimana nilai BOD, TSS, $\mathrm{NH}_{3}$ dan DO pada lahan aplikasi lebih besar dari nilai yang ada di lahan non aplikasi sebagai lahan kontrol dan dimana konsentrasi BOD dan DO pada hilir sungai lebih 
besar dari konsentrasi pada hulu sungai. Konsentrasi TSS dan $\mathrm{NH}_{3}$ pada air permukaan dipengaruhi oleh faktor luar, yaitu penyedotan air oleh perusahaan Sedangkan nilai pH masih berada dalam rentang normal.

b. Penyebaran kontaminan pada lahan aplikasi dipengaruhi oleh beberapa hal seperti kondisi lahan, dekatnya muka air tanah dengan permukaan tanah, adanya cekungan dan bentuk aliran air tanah pada lahan. Namun ada beberapa penyimpangan yang terjadi akibat adanya faktor lain seperti TSS yang menurun pada titik kedua pada lahan aplikasi disebabkan adanya aliran lain dari parit yang terletak di dekat titik kedua, sehingga air tanah pada titik kedua terencerkan.

Sedangkan pada lahan non aplikasi, adanya fitoremediasi di lahan pada titik ketiga, keempat dan titik kelima yang merupakan vegetasi semak yang cukup rimbun sehingga kontaminan terdegradasi. Adanya kejanggalan pada titik kedua dan ketiga pada penyebaran TSS yang disebabkan adanya bahan-bahan lain dalam tanah, seperti partikel tanah itu sendiri yang bercampur dengan air tanah sehingga menyebabkan konsentrasi TSS oleh bahan organik sulit ditentukan.

\section{Ucapan Terima Kasih}

Penulis mengucapkan terima kasih kepada Tuhan YME, kedua orang tua, dosen pembimbing Dr. Ir. Marsudi, M.Sc dan Winardi Yusuf, ST, MT, PT.MISP Bengkayang, PT.SUCOFINDO Pontianak, kepada teman-teman Teknik Lingkungan 2010 serta semua pihak yang telah berperan dalam proses dan penyelesaian penelitian ini.

\section{Referensi}

Effendi, Hefni. 2003. Telaah Kualitas Air Bagi Pengelolaan Sumber Daya Lingkungan Perairan. Yogyakarta. PT Kanisius.

Fardiaz, Srikandi. 1992. Polusi Air dan Udara. Yogyakarta. Kanisius.

Floyd RF, Watson C, Petty D, Pouder DB. 2009. Ammonia in Aquatic System.http://defishery.files.wordpress.com/2009/11/sistem-ammonia-di-perairan.pdf

Keputusan Menteri Negara Lingkungan Hidup Nomor 28 Tahun 2003 tentang Pedoman Teknis Pengkajian Pemanfaatan Air Limbah dari Industri Minyak Sawit Pada Tanah di Perkebunan Kelapa Sawit.

Nopianto, Eko S. 2010. Analisa Potensi Biomassa Pada Pabrik Pengolahan Kelapa Sawit PT. Inti Indosawit Subur, PMKS Tungkal Ulu Tanjung Jabung Barat, Provinsi Jambi. Laporan Praktek Kerja Lapangan Jurusan Teknologi Industri Pertanian Fakultas Teknologi Pertanian Institut Pertanian Bogor. Bogor. IPB

Peraturan Pemerintah Republik Indonesia Nomor 82 Tahun 2001 Tentang Pengelolaan Kualitas Air dan Pengendalian Pencemaran Air.

Piscopo, G. 2001. Groundwater Vulnerability Map Explanatory Notes. http://www.waterwise.nsw.gov.au/water/pdf/lachlan_map_notes.pdf

Rahayu S, Widodo RH, van Noordwijk M, Suryadi I dan Verbist B. 2009. Monitoring Air di Daerah Aliran Sungai. Bogor, Indonesia. World Agroforesty Centre - Southeast Asia Regional Office.

Salmin. 2005. Oksigen Terlarut (DO) Dan Kebutuhan Oksigen Biologi (BOD) Sebagai Salah Satu Indikator Untuk Menentukan Kualitas Perairan, Volume XXX. Oseana.

Verstappen. H. Th and Zuidam, R. A. Van. 1975. ITC Texbook of Photointerpretation vol VII, Chapter VII.2 ITC System of Geomorphological Survey: Use of Aerial of Photographs in Geomorphology. Enschede. International Institute fo Aerial Survey and Earth Sciences. 